\title{
Screening of Chloroform and Methanolic Bark Extracts of Commiphora caudata for its In-vitro Anti-bacterial, Anti-fungal and In-vivo Anti-inflammatory Activity
}

\author{
Research Article
}

\section{Raju HV1, Kishori P Sutar ${ }^{2 *}$, Prasanna S Sutar ${ }^{3}$, Shailendra S Suryawanshi ${ }^{4}$, Nisha S Shirkoli ${ }^{5}$}

\begin{abstract}
1. Professor, Department of Pharmacognosy, V V Puram College of Pharmacy, Bengaluru, Rajiv Gandhi University of Health Sciences, Bengaluru, Karnataka. India.

2. Assistant Professor, Department of Pharmaceutics, KLE College of Pharmacy, Belagavi, KLE Academy of Higher Education and Research, Nehru Nagar, Belagavi, Karnataka. India.

3. Professor, Department of Pharmacognosy, Maratha Mandal's College of Pharmacy, Belagavi, Karnataka. India. 4. Assistant Professor, Department of Pharmaceutical Chemistry, KLE College of Pharmacy Belagavi, KLE Academy of Higher Education and Research, Belagavi, Karnataka. India.

5. Assistant Professor, Department of Pharmaceutical Quality Assurance, KLE College of Pharmacy, Belagavi, KLE Academy of Higher Education and Research, Nehru Nagar, Belagavi, Karnataka. India.
\end{abstract}

\begin{abstract}
Herbal medicines and their preparations have been widely used from the thousands of years in developing and developed countries in the primary health care of society and community. They have great demand due its safety, efficacy with minimum side or adverse effects. Commiphora caudata. It's known as konda mava in kannada, ikkata in Sanskrit and hill mango in English. It's widely used in the management of various disorders. Hence the identification of bioactive fractions from various parts of selected medicinal plant is important. In the present research work an attempt has been made to screen and assess the antibacterial, antifungal and anti-inflammatory activities of Commiphora caudata barks. The barks of selected plant material were collected, authenticated, powdered and subjected for extraction procedure. The extracts were screened for presence of various phytoconstituents. The antibacterial activity of chloroform and methanolic extracts were performed against various strains of bacteria and fungi. The extracts also were investigated for its in-vivo anti-inflammatory activity. The result of investigation concludes that chloroform and methanolic extract of plant were potential to inhibit the growth of selected strains of microorganism and also produced potential anti-inflammatory effect.
\end{abstract}

Key Words: Anti-bacterial, Anti-fungal, Anti-inflammatory, Commiphora caudata, Bark Extracts, Herbal Medicines.

\section{Introduction}

Commiphora caudata belongs to the family of Burseraceae belongs to genus Commiphora. It's known as konda mava in kannada, ikkata in Sanskrit and hill mango in English (1). It is found in India: Karnataka, Andhra Pradesh, Kerala, Tamilnadu and Srilanka (2). From ancient times, the plants have been used as raw material for cosmetics, pharmaceuticals, botanical pesticides, disinfectants, insect repellents, herbal teas, herbal drinks, etc. Chemical constituents of plant origin have long been known to possess several biological activities (3). It is estimated that about $50,000-70,000$ plant species are used in traditional and

* Corresponding Author:

\section{Kishori P Sutar}

Assistant Professor, Department of Pharmaceutics,

KLE College of Pharmacy, Belagavi,

KLE Academy of Higher Education and Research, Nehru Nagar, Belagavi-590010, Karnataka, India.

Email Id: kishorirg@gmail.com modern medicine throughout the World. These species make a significant contribution to healthcare and along with species used for their aromatic properties, in herbal products, pharmaceuticals and fragrances (4). The essential oils are effective against microorganisms, and have been recognized as natural antioxidants. Plant pacifies vitiated vatta, pitta, diabetes, low back pain, sciatica, fever, arthritis, urinary retention, antibacterial antiulcer, hepatoprotective, antioxidant etc and Seed used to relive stomach ache $(5,6)$ The literature survey revealed that many of the Commiphora species contain Sterols, Terpenes, Flavonoids, Resins and Tannins, Polyphenols. A survey of literature (7-9) revealed that Commiphora caudata is used for the treatment of inflammation but lack of scientific data is available on its anti-inflammatory activity. Keeping in view, the anti-inflammatory activity of bark is evaluated.

\section{Materials and Methods}

Collection and Identification of Plant Material

The barks of Commiphora caudata were collected around the local area of Mandya (Karnataka), 
authenticated by Regional Research Institute, Bangalore (Karnataka).

\section{Chemicals and Reagents}

All solvents methanol, ethanol, chloroform and ethyl acetate used for extraction purpose were purchased from Merk. The chemicals and reagents used for phytochemistry research were obtained from store house of Maratha Mandal College of Pharmacy, Belagavi. Standard drug Ciprofloxacin was procured from Micro Labs, Bengaluru.

\section{Preparation of Bark Extracts}

The barks of the plant were collected, washed and air dried. They were powdered in Willy mill and successively extracted in chloroform and methanol. Extraction was carried out by using soxhlet. The extracts were concentrated under vacuum to get the residues. The residues were weighed and percentage yield was calculated. They were then stored in well closed container for phytochemical and pharmacological evaluation.

\section{Phytochemical Screening of the bark extracts}

The phytochemical evaluation was performed for both the extracts to detect the presence of various chemical constituents (10-16).

\section{Screening of Antibacterial, Antifungal and Anti-} inflammatory Activities

In-vitro antibacterial (17-19) and antifungal activities and in-vivo anti-inflammatory (5-7, 17-21) activities were examined for both the extracts. The antibacterial activity of bark extracts was screened against eight pathogenic bacterial strains, Bacillus subtilis, Escherichia coli, Bacillus pumilis, Pseudomonas aeruginosa, Bacillus cerus, Pseudomonas vulgaris, Staphylococcus aureus and Serratia marcens respectively. The antifungal activity was screened for three pathogenic fungi strains Aspergillus Niger, Saccharomyces cereviceae, and Penicillin chrysozenum. Antifungal activity was investigated by the agar disk diffusion method. The antibacterial activity testing carried out by using agar cup method. Each purified extracts were dissolved in dimethyl sulfoxide, sterilized by filtration using sintered glass filter, and stored at $4^{\circ} \mathrm{C}$. For the determination of zone of inhibition, pure bacterial and fungal strains were taken as a standard antibiotic for comparison of the results. Control experiments were carried out under similar condition by using Amoxicillin for antibacterial activity and Ketoconazole for antifungal activity as standard drugs. The zones of growth inhibition around the disks were measured after 18 to 24 hours of in incubation at $37^{\circ} \mathrm{C}$ for bacteria and 48 to 96 hours for fungi at $28^{\circ} \mathrm{C}$. The sensitivities of the microorganism species to the plant extracts were determined by measuring the sizes of inhibitory zones (including the diameter of disk) on the agar surface around the disks, and values $<8 \mathrm{~mm}$ were considered as not active against microorganisms.
Screening of in-vivo Anti-inflammatory activity by Carrageenan-induced paws edema method in rats.

In this method $0.1 \mathrm{ml}$ of $1 \%$ carrageenan in $0.9 \%$ sterile normal saline solution (NSS) was injected subcutaneously into the sub plantar area of right hind paw of the rats to induce edema.

Male rats weighing between $200-250 \mathrm{~g}$ were selected, housed under laboratory temperature and were divided into eight groups (17-20). Each group consisting of six rats each and details were presented in Table 1.

\section{Table 1: Groups for Animal Experiment}

\begin{tabular}{c|l}
$\begin{array}{c}\text { Groups } \\
\text { Group } \\
\text { I }\end{array}$ & $\begin{array}{l}\text { Details of treatment } \\
(\text { Control }) \text { which was served with Normal } \\
\text { Saline. }\end{array}$ \\
$\begin{array}{c}\text { Group } \\
\text { II }\end{array}$ & $\begin{array}{l}\text { (Standard) which was served with Ibuprofen } \\
(10 \mathrm{mg} / \mathrm{kg})\end{array}$ \\
$\begin{array}{c}\text { Group } \\
\text { III }\end{array}$ & $\begin{array}{l}\text { (Chloroform extract Commiphora caudata }) \\
\text { which wa served with Chloroform extract } \\
(100 \mathrm{mg} / \mathrm{kg})\end{array}$ \\
Group & $\begin{array}{l}\text { (Chloroform extract Commiphora caudata }) \\
\text { which was served with Chloroform extract } \\
\text { IV }\end{array}$ \\
$\begin{array}{c}(300 \mathrm{mg} / \mathrm{kg}) \\
\text { Group }\end{array}$ & $\begin{array}{l}\text { (Chloroform extract Commiphora caudata }) \\
\text { which was served with Chloroform extract } \\
(500 \mathrm{mg} / \mathrm{kg})\end{array}$ \\
Group & $\begin{array}{l}(\mathrm{Methanolic} \text { extract Commiphora caudata }) \\
\text { which was served with methanolic extract } \\
(100 \mathrm{mg} / \mathrm{kg})\end{array}$ \\
Group & $\begin{array}{l}\text { (Methanolic extract Commiphora caudata }) \\
\text { which was served with methanolic extract } \\
(300 \mathrm{mg} / \mathrm{kg}) .\end{array}$ \\
VII & $\begin{array}{l}\text { (Methanolic extract Commiphora caudata }) \\
\text { which was served with methanolic extract } \\
(500 \mathrm{mg} / \mathrm{kg})\end{array}$ \\
Group \\
VIII
\end{tabular}

Each group was orally administered 5\% Tween 80 , Ibuprofen $(10 \mathrm{mg} / \mathrm{kg})$, and various doses of Methanolic Extract (ME) and Chloroform Extract (CE) $(100,300$, and $500 \mathrm{mg} / \mathrm{kg})$ and as the control, reference, and test group, respectively. Samples were feed one hour prior to carrageenan injection. The edema volumes were determined using a plethysmometer at 1,3 , and 5 $\mathrm{hr}$ after carrageenan injection. Results were expressed as mean \pm SEM compared with the control group at each time interval. Statistical significance was determined by one-way analysis of variance (ANOVA) at the $95 \%$ confidence interval. The Percentage inhibition of edema was calculated for each group with respect to the control group.

$$
\% \text { inhibition }=100[1-(\mathrm{Vt}-\mathrm{Vc})]
$$

Where,

$\mathrm{Vt}$ and $\mathrm{Vc}$ are the volumes of carrageenan-induced paws of the drug treated group and control group respectively.

\section{Results}

\section{Phytochemical extraction and screening of bark} extracts

The residue of Chloroform extract Commiphora caudata was dark brownish in color, gave positive Libermann Buchard reactions for Sterols (pink-blue- 
green) and tri-terpenoids and positive test for ferric chloride (olive green). The methanolic extract residue of Commiphora caudata was dark reddish in color, gave positive Libermann Buchard reaction for sterols, triterpenoids and flavonoids.

\section{Anti-bacterial activity}

The antibacterial activity of the extracts was studied in different concentrations on eight pathogenic bacterial strains, Bacillus subtilis, Escherichia coli, Bacillus pumilis, Pseudomonas aeruginosa, Bacillus cerus, Pseudomonas vulgaris, Staphylococcus aureus and Serratia marcens and three pathogenic fungi Aspergillus Niger, Saccharomyces cereviceae, and Penicillin chrysozenum. Antibacterial and antifungal potential of extracts were assessed in terms of zone of inhibition of bacterial growth. The results of the antibacterial and antifungal activities are presented in Table 2 and Table 3 respectively. The chloroform and methanolic extracts of Commiphora caudata posses potential antibacterial activity against Gram $(+)$ ve and Gram (-) ve organisms (Bacillus subtilis, Bacillus pumili, Bacillus cerus, Staphylococcus aureus, Escherichia coli, Pseudomonas aeruginosa, Pseudomonas vulgaris, Serratia marcens).

When tested by the disc diffusion method, the chloroform extracts $100 \mathrm{mg} / \mathrm{ml}$ and $300 \mathrm{mg} / \mathrm{ml}$ showed mild activity against Staphylococcus aureus, Serratia marcens around $13 \mathrm{~mm}$ highest zone of inhibition. The lowest activity was seen in Bacillus subtilis, Pseudomonas vulgaris i.e., around $08 \mathrm{~mm}$ zone of inhibition. The methanolic extract $100 \mathrm{mg} / \mathrm{ml}$ and $300 \mathrm{mg} / \mathrm{ml}$ showed moderate activity. The highest activity of $24 \mathrm{~mm}$ zone of inhibition was seen in Serratia marcens and least activity was recorded in Bacillus subtilis, measured $16 \mathrm{~mm}$ zone of inhibition. The activity increased with increasing concentrations. However, the activity by the extract was low when compared with of standard Amoxicillin around $28 \mathrm{~mm}$ zone of inhibition in Bacillus subtilis.

\section{Table 2: Anti-bacterial activity of barks of Commiphora caudata}

\begin{tabular}{|c|c|c|c|c|c|c|c|c|c|}
\hline Extract & Concentration & BS & $\mathbf{B P}$ & $\mathbf{B C}$ & SA & EC & PA & PV & SM \\
\hline \multirow{2}{*}{ Chloroform extract } & $(100 \mathrm{mg} / \mathrm{ml})$ & 8 & 10 & 11 & 12 & 10 & 9 & 8 & 11 \\
\hline & $(300 \mathrm{mg} / \mathrm{ml})$ & 9 & 11 & 11 & 13 & 12 & 12 & 11 & 13 \\
\hline \multirow{2}{*}{ Methanolic extract } & $(100 \mathrm{mg} / \mathrm{ml})$ & 12 & 15 & 16 & 15 & 16 & 14 & 16 & 17 \\
\hline & $(300 \mathrm{mg} / \mathrm{ml})$ & 16 & 17 & 16 & 18 & 17 & 18 & 17 & 20 \\
\hline Amoxicillin & $10 \mu \mathrm{g} / \mathrm{ml}$ & 28 & 23 & 21 & 24 & 18 & 20 & 18 & 24 \\
\hline
\end{tabular}

*BS: Bacillus subtilis, EC: Escherichia coli, BP: Bacillus pumilis, PA: Pseudomonas aeruginosa, BC: Bacillus cerus, PV: Pseudomonas vulgaris, SA: Staphylococcus aureus and SM: Serratia marcens

Table 3: Antifungal activity of barks of Commiphora caudata

\begin{tabular}{|c|c|c|c|c|}
\hline Extract & $\begin{array}{c}\text { Concentratio } \\
\mathbf{n}\end{array}$ & AN & SC & PC \\
\hline $\begin{array}{c}\text { Chloroform } \\
\text { extract }\end{array}$ & $(100 \mathrm{mg} / \mathrm{ml})$ & 12 & 12 & 14 \\
\hline $\begin{array}{c}\text { Methanolic } \\
\text { extract }\end{array}$ & $(100 \mathrm{mg} / \mathrm{ml})$ & 15 & 17 & 16 \\
\hline Ketoconazole & $(300 \mathrm{mg} / \mathrm{ml})$ & 19 & 20 & 19 \\
\hline
\end{tabular}

*AN: Aspergillus Niger, SC: Saccharomyces cereviceae, PC: Penicillin chrysozenum.

\section{Anti-inflammatory Activity}

The in vivo anti-inflammatory activities of both extracts were confirmed by the carrageenan-induced paw edema model. The oral administration of methanolic extract at the dose of $500 \mathrm{mg} / \mathrm{kg}$ reduced the swollen of carrageenan-induced paw edema with significant difference from control at 1, 3, and $5 \mathrm{hr}$ and was not different from the standard drug, Ibuprofen (Figure 2). Oral administration of chloroform extract at the concentration of $500 \mathrm{mg} / \mathrm{kg}$ showed the antiinflammatory activity by inhibiting the acute phase of inflammation. Based on the inhibitory effect of the CE seen at the $3^{\text {rd }} \mathrm{hr}$ and $5^{\text {th }} \mathrm{hr}$, it suggests that the main mechanism of action may be due to inhibition of PGs synthesis. Moreover, the inhibitory effect of the extracts may partly involve other acute inflammatory mediators such as histamine, serotonin, bradykinin, and proinflammatory cytokines which are released during the $1^{\text {st }} \mathrm{hr}$ after carrageenan injection. The results were tabulated and data is statistically analyzed using one- way ANOVA followed by Dunnet's test \& results were presented in the Table 4 and Table 5.

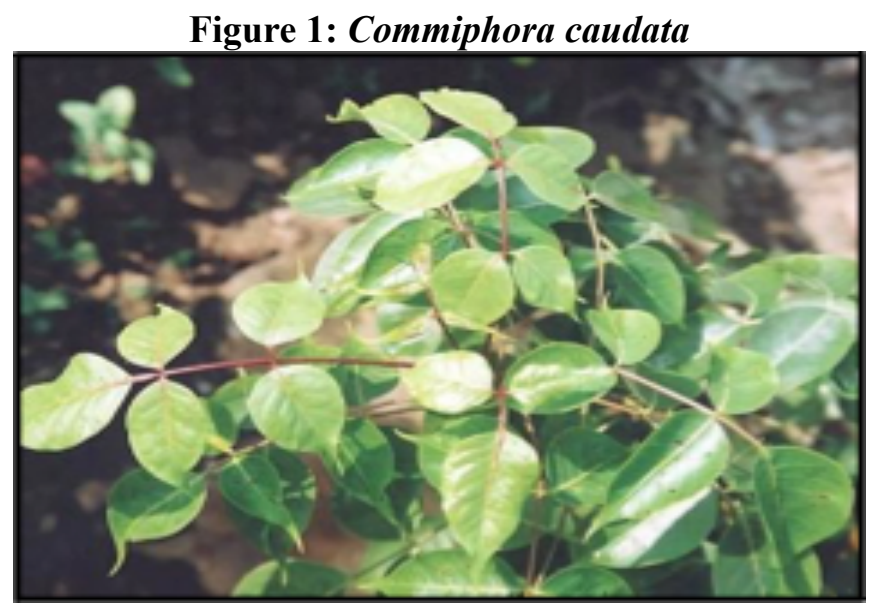

Figure 2: The edema volume of rat paw

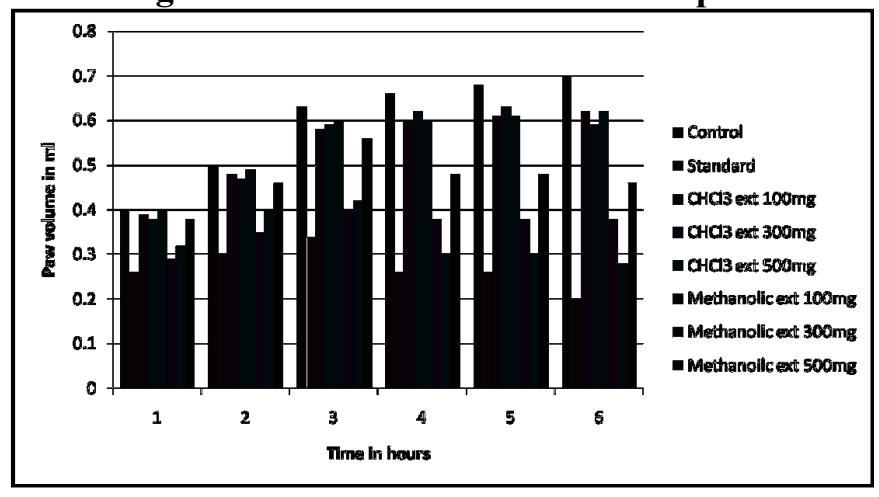


Raju HV et.al., Screening of Chloroform and Methanolic bark extracts of Commiphora caudate for its in-vitro biological activities

Table 4: Anti inflammatory activity of Commiphora caudata bark extracts

\begin{tabular}{|c|c|c|c|c|c|c|c|}
\hline \multirow{2}{*}{ Treatment } & \multirow{2}{*}{ Dose } & \multicolumn{6}{|c|}{ Volume of mercury displaced in $\mathrm{ml}$ at various time intervals in hours. } \\
\hline & & $\mathbf{0}$ & 1 & 2 & 3 & 4 & 5 \\
\hline Control & $0.1 \mathrm{ml} 1 \% \mathrm{~W} / \mathrm{V}$ & $0.40 \pm 0.025$ & $\begin{array}{l}0.50 \pm \\
0.057\end{array}$ & $0.63 \pm 0.057$ & $0.66 \pm 0.057$ & $0.68 \pm 0.057$ & $0.70 \pm 0.058$ \\
\hline Ibuprofen & $10 \mathrm{mg} / \mathrm{kg}$ & $0.26 \pm 0.005$ & $\begin{array}{c}0.30 \pm * * * \\
0.005\end{array}$ & $\begin{array}{c}0.34 \pm * * * \\
0.002\end{array}$ & $\begin{array}{c}0.26 \pm * * * \\
0.003\end{array}$ & $\begin{array}{c}0.26 \pm * * * \\
0.003\end{array}$ & $\begin{array}{c}0.20 \pm * * * \\
0.04\end{array}$ \\
\hline $\begin{array}{l}\text { Chloroform } \\
\text { Ext. of C.C. }\end{array}$ & $100 \mathrm{mg} / \mathrm{kg}$ & $0.39 \pm 0.01$ & $\begin{array}{c}0.48 \pm \mathrm{NS} \\
0.01\end{array}$ & $\begin{array}{c}0.58 \pm \mathrm{NS} \\
0.02\end{array}$ & $\begin{array}{c}0.60 \pm \mathrm{NS} \\
0.01\end{array}$ & $\begin{array}{c}0.61 \pm \mathrm{NS} \\
0.01\end{array}$ & $\begin{array}{c}0.62 \pm \mathrm{NS} \\
0.01\end{array}$ \\
\hline $\begin{array}{l}\text { Chloroform } \\
\text { Ext. of C.C. }\end{array}$ & $300 \mathrm{mg} / \mathrm{kg}$ & $\begin{array}{c}0.38 \pm \\
0.01\end{array}$ & $\begin{array}{c}0.47 \pm \mathrm{NS} \\
0.03\end{array}$ & $\begin{array}{c}0.59 \pm \mathrm{NS} \\
0.05\end{array}$ & $\begin{array}{c}0.62 \pm \mathrm{NS} \\
0.04\end{array}$ & $\begin{array}{c}0.63 \pm \mathrm{NS} \\
0.03\end{array}$ & $\begin{array}{c}0.59 \pm \mathrm{NS} \\
0.02\end{array}$ \\
\hline $\begin{array}{l}\text { Chloroform } \\
\text { Ext of C.C }\end{array}$ & $500 \mathrm{mg} / \mathrm{kg}$ & $\begin{array}{c}0.40 \pm \\
0.01\end{array}$ & $\begin{array}{c}0.49 \pm \mathrm{NS} \\
0.01\end{array}$ & $\begin{array}{c}0.60 \pm \mathrm{NS} \\
0.02\end{array}$ & $\begin{array}{c}0.60 \pm \mathrm{NS} \\
0.01\end{array}$ & $\begin{array}{c}0.61 \pm \mathrm{NS} \\
0.03\end{array}$ & $\begin{array}{c}0.62 \pm \mathrm{NS} \\
0.04\end{array}$ \\
\hline $\begin{array}{l}\text { Methanolic } \\
\text { Ext of C.C }\end{array}$ & $100 \mathrm{mg} / \mathrm{kg}$ & $0.29 \pm 0.01$ & $\begin{array}{l}0.35 \pm * * \\
0.02\end{array}$ & $\begin{array}{c}0.40 \pm * * \\
0.05\end{array}$ & $\begin{array}{c}0.38 \pm * * * \\
0.03\end{array}$ & $\begin{array}{c}0.38 \pm * * * \\
0.01\end{array}$ & $\begin{array}{c}0.38 \pm * * * \\
0.04\end{array}$ \\
\hline $\begin{array}{l}\text { Methanolic } \\
\text { Ext of C.C }\end{array}$ & $300 \mathrm{mg} / \mathrm{kg}$ & $0.32 \pm 0.01$ & $\begin{array}{l}0.40 \pm * * \\
0.02\end{array}$ & $\begin{array}{c}0.42 \pm * * \\
0.05\end{array}$ & $\begin{array}{c}0.30 \pm * * * \\
0.03\end{array}$ & $\begin{array}{c}0.30 \pm * * * \\
0.01\end{array}$ & $\begin{array}{c}0.28 \pm * * * \\
0.04\end{array}$ \\
\hline $\begin{array}{l}\text { Methanolic } \\
\text { Ext of C.C }\end{array}$ & $500 \mathrm{mg} / \mathrm{kg}$ & $0.38 \pm 0.01$ & $\begin{array}{c}0.46 \pm * * \\
0.02\end{array}$ & $\begin{array}{c}0.56 \pm * \\
0.05\end{array}$ & $\begin{array}{c}0.48 \pm * \\
0.03\end{array}$ & $\begin{array}{c}0.48 \pm * * \\
0.01\end{array}$ & $\begin{array}{c}0.46 \pm * * \\
0.04\end{array}$ \\
\hline
\end{tabular}

Significance of difference in control and extracts treated groups were determined by one way analysis of variance (ANOVA) *** $\mathrm{P}<0.001 * * \mathrm{P}<0.01,{ }^{*} \mathrm{P}<0.05$ are significant and ${ }^{\mathrm{NS}} \mathrm{P}>0.05$, are not significant. All values are means of individual data obtained from six rats $(\mathrm{n}=6)$

Table 5: Percentage inhibition of Commiphora caudata bark extracts

\begin{tabular}{|c|c|c|c|c|c|c|c|}
\hline \multirow[t]{2}{*}{ Treatment } & \multirow[t]{2}{*}{ Dose } & \multicolumn{6}{|c|}{$\begin{array}{c}\% \text { Inhibition of paw volume at various time } \\
\text { Intervals }\end{array}$} \\
\hline & & $\mathbf{0}$ & 1 & 2 & 3 & 4 & 5 \\
\hline Control & $0.1 \mathrm{ml} \% \mathrm{~W} / \mathrm{V}$ & 0 & 0 & 0 & 0 & 0 & 0 \\
\hline Ibuprofen & $10 \mathrm{mg} / \mathrm{kg}$ & 0 & 40 & 46.03 & 60.60 & 61.76 & 71.42 \\
\hline Methanolic Extract & $100 \mathrm{mg} / \mathrm{kg}$ & 0 & 30 & 36.5 & 42.42 & 44.11 & 45.71 \\
\hline Methanolic Extract & $300 \mathrm{mg} / \mathrm{kg}$ & 0 & 20 & 33.33 & 54.14 & 55.88 & 61.42 \\
\hline Methanolic Extract & $500 \mathrm{mg} / \mathrm{kg}$ & 0 & 8 & 11.11 & 27.27 & 29.41 & 34.28 \\
\hline Chloroform Extract & $100 \mathrm{mg} / \mathrm{kg}$ & 0 & 4 & 7.3 & 9.09 & 10 & 11.4 \\
\hline Chloroform Extract & $300 \mathrm{mg} / \mathrm{kg}$ & 0 & 6 & 6.3 & 6.06 & 7.3 & 15 \\
\hline Chloroform Extract & $500 \mathrm{mg} / \mathrm{kg}$ & 0 & 2 & 4.5 & 9.09 & 10 & 11.4 \\
\hline
\end{tabular}

\section{Discussion}

The residue of Chloroform extract Commiphora caudata was dark brownish in color, gave positive Libermann Buchard reactions for Sterols (pink-bluegreen) and tri-terpenoids and positive test for ferric chloride (olive green). The methanolic extract residue of Commiphora caudata was dark reddish in color, gave positive Libermann Buchard reaction for sterols, triterpenoids and flavonoids. The antibacterial activity of the extracts was studied in different concentrations on eight pathogenic bacterial strains, and three pathogenic fungi. The in vivo anti-inflammatory activities of both extracts were confirmed by the carrageenan-induced paw edema model. The oral administration of methanolic extract at the dose of 500 $\mathrm{mg} / \mathrm{kg}$ reduced the swollen of carrageenan-induced paw edema with significant difference from control at 1,3 , and $5 \mathrm{hr}$ and was not different from the standard drug, Ibuprofen.

\section{Conclusion}

Herbal medicines and their preparations have been widely used from the thousands of years in developing and developed countries in the primary health care of society and community. Our findings strongly confirmed the chloroform and methanolic bark extract of selected plant has potential anti-microbial and antiinflammatory activity. We have screened and assessed the antibacterial, antifungal and anti-inflammatory activities of Commiphora caudata barks. The chloroform and methanolic extracts of Commiphora caudata bark found to posses potential antibacterial activity against Gram (+) ve and Gram (-) ve organisms. It is also exerting its antifungal activity against different strains. The in vivo anti-inflammatory activities of both extracts were confirmed by the carrageenan-induced paw edema model.

\section{Acknowledgement}

The authors are deeply indebted to Professor C. Ramesh, V.V. Puram College of Pharmacy, and Bengaluru for providing laboratory facilities to carry out this project.

\section{List of Abbreviations}

BS: Bacillus subtilis,

EC: Escherichia coli,

BP: Bacillus pumilis,

PA: Pseudomonas aeruginosa, 
BC: Bacillus cerus,

PV: Pseudomonas vulgaris,

SA: Staphylococcus aureus

SM: Serratia marcens,

AN: Aspergillus Niger,

SC: Saccharomyces cereviceae,

PC: Penicillin chrysozenum

\section{Reference}

1. Yoganarasimhan S. N. Medicinal Plants of India: Karnataka; Vol 1. Bangalore; Interline Publishing Pvt Ltd; 1996. 433-434p.

2. Cragg GM, Boyd MR, Cardellina JH, Grever M. Human Medicinal Agents from Plants. Washington; ACS Symposium Series, No. 534; 1993. 80p.

3. Kirtikar K.R, Basu B.D. Indian Medicinal Plant. Ed 1; Vol 1. Allahabad; International book distributors; 1935. 308-406p.

4. Akindele AJ, Adeyemi O.O. Anti-inflammatory activity of the aqueous leaf extract of Byrsocarpus coccineus. Fitoterapia. 2007; 78; 25-28.

5. Kirtikar K.R, Basu B.D. Indian Medicinal Plant. Ed 1; Vol 1. Allahabad; International book distributors; $1935.525-527 \mathrm{p}$.

6. Orient Longman, Indian Medicinal Plants. A Compendium of 500 Species. Ed 1: Vol 1. New Delhi; Orient Blackswan Private Limited; 2007. $2: 125 \mathrm{p}$.

7. Shen T, Li GH, Wang XN, Lou HX. The genus Commiphora: a review of its traditional uses, phytochemistry and pharmacology. Journal of ethnopharmacology. 2012;142(2):319-30.

8. Dhivya PS, Selvamani P, Latha S, Mani V, Azahan NS. In Vitro Evaluation of Acetylcholinesterase Inhibitory and Neuroprotective Activity in Commiphora species: A Comparative Study. Pharmacognosy Journal. 2020; 14:12(6).

9. Srinivasan P, Arul B, Kothai R. Neuroprotective effect of ethanolic leaf extract of Commiphora caudata (Wight \&Arn) against lipopolysaccharide- induced neurotoxicity in Wistar rats. Journal of Herbmed Pharmacology. 2021;10(4).

10. Kokate C.K, Purohit A.P. Practical Pharmacognosy. Ed 4. Delhi; Vallabh Prakashan; 1994. 54-60p.

11. Peach K and Tracey MV. Modern methods of Plant analysis. Ed 211. New York; Springer Publishers; 1955. 3: 467-478p.

12. Pulok K. M. Quality control of Herbal Drugs. Ed 1. Amsterdam; Elsevier; 2002. 540-542p.

13. Brain K.R. and Turner T.D. The Practical Evaluation of Phytopharmaceuticals. Bristol; Wright Scientechina; 1975. 155p

14. Brunteon J. Pharmacognosy, Phytochemistry, Medicinal Plants. Amsterdam; Elsevier; 1992. 2: 225-39p.

15. Khandelwal K R. Practical Pharmacognosy. Pune; Nirali Prakashan; 1995. 140-143p.

16. Indian Herbal Pharmacopoeia. Dehli; Controller of Publications; 1996. 209-210p.

17. Saha A, Ahmeed M. The analgesic and antiinflammatory activities of the extract of albizia lebbeck in animal model. Pak. J. Pharm. Sci. January 2009; 22(1); 74-77.

18. Annu W, Latha P, Shaji J, Anti- inflammatory, analgesic and anti- lipid peroxidation studies on leaves of Commiphora caudata. Indian Journal of Natural Products and resources. March 2010; 1; 44 $-48$.

19. Elisha IL, Botha FS, McGaw LJ, Eloff JN. The antibacterial activity of extracts of nine plant species with good activity against Escherichia coli against five other bacteria and cytotoxicity of extracts. BMC complementary and alternative medicine. 2017;17(1):1-0.

20. Abdullahi M, Nuhu N, Evaluation of analgesic and anti-inflammatory activities of n-butanol phase of the leaves extract of Microtrichia perotitii DC. Journal of Medicinal plants Research. May 2010; 4(9);722-725.

21. Vogel H.G. Drug discovery and evaluation. Ed 3. New York; Springer Publishers; 2002. 2: 755-769p. 